\title{
EXPERIMENTAL INVESTIGATION OF UHPC USING ACID AND CHLORIDE PONDING TESTS
}

\author{
Monish $\mathbf{S}^{1}$, Shiva Kumar $\mathrm{KS}^{2}$, Manoj $\mathbf{V}^{3}$ \\ ${ }^{1}$ MTech Civil Structural Engineering, Global Academy of Technology, Bangalore-98 \\ ${ }^{2}$ Professor (Department of Civil Engineering, Global Academy of Technology, Bangalore-98 \\ ${ }^{3}$ MTech Civil Structural Engineering, Global Academy of Technology, Bangalore-98 \\ manojvconcrete90@gmail.com
}

\begin{abstract}
This paper presents the development of Ultra High Performance Fibre reinforced Concrete (UHPFRC) using mineral admixtures. UHPFRC mixture proportions were developed using local materials such as Micro silica and Metakaolin. The Ultra-High Performance Concrete (UHPC) used in this study is steel fibre reinforced concrete consisting of an optimized gradation of both fine and coarse agg along with different water/cement ratios. Experimental investigation was carried out for two different UHPFRC mixes Mixl (without CA) and Mix2 (with CA) with different water cement ratio of 0.3, 0.28, 0.26 and 0.24 respectively. Both the UHPFRC mix had same values of steel fibre in terms of volume fraction (0.5\%). It was found that Mix 1 with W/C ratio 0.24 has more compressive strength when compared to Mix $2 \mathrm{~W} / \mathrm{C}$ ratio 0.24 and other W/C ratios.
\end{abstract}

Keywords - Ultra-High Performance Concrete, Metakaolin, Micro silica, steel fibres, ACID Test, Chloride Ponding Test

\section{INTRODUCTION}

The term Ultra High Performance concrete is used to define a concrete having fibre reinforcement, superplasticizer, cementitious materials with very low w/c ratio characterized by the presence of Quartz sand instead of coarse aggregates for Mix 1 and the other mix by using $12.5 \mathrm{~mm}$ down size coarse aggregates along with Quartz sand for Mix2. The absence of coarse aggregates in Mix 1 is done mainly to obtain proper microstructure and the performance of Ultra high performance concrete in order to reduce the heterogeneity between the aggregates and the cement matrix. The work is carried out by using four different water to cement ratios of $0.24,0.26,0.28$ and 0.3 for Mix 1 (cement density $700 \mathrm{~kg} / \mathrm{m} 3$ ) and Mix 2 (cement density $700 \mathrm{~kg} / \mathrm{m} 3$ ) including both fine aggregates and coarse aggregates in addition with mineral admixtures such as Micro Silica (10\%) and Metakaolin (5\%) and steel strands (0.5\%). Different material tests are conducted on cement, $\mathrm{M}$ sand (FA), coarse aggregate to determine specific density, water absorption, etc. Workability tests such as slump test, L box, etc are conducted and durability test are also conducted such as RCPT, Sulphate attack test. The procedure for Mix design of UHPC is carried out by using particle packing density method since there are no proper mix design codes. The mix proportions arrived in this study is taken by referring from author H.J.H. Brouwers et.al, from Cement and Concrete Research journal published on November 2013.

\section{MATERIALS}

\subsection{Cement}

The Ordinary Portland cement of 53-grade was used in this study conforming to IS: $12269-1987$.The specific gravity of cement is 3.15

\subsection{Micro Silica}

A white undensified Silica Fume (SF) with Blaine fineness about $200(\mathrm{~m} 2 / \mathrm{g})$ is a pozzolanic material which has a high content of amorphous silicon dioxide and consists of very fine spherical particles. It reacts with calcium hydroxide $\mathrm{Ca}(\mathrm{OH})_{2}$, producing calcium silicate hydrate (secondary gel). It is added as partial replacement by weight of cement. The specific gravity of silica fume is 2.2

\subsection{Metakaolin}

It is the most foremost natural minerals that are made by heat-treating china clay. China clay could be a fine, the term china clay springs from metakaolin that is often contains $50-55 \% \quad \mathrm{SiO} 2$ and $40-45 \%$ of $\mathrm{AL}_{2} \mathrm{O}_{3}$. Metakaolin particles are usually $1 \mathrm{~mm}$ to 5 microns in diameter, bigger than micro Silica fume particles. In this study $5 \%$ of metakaolin is used as partial replacement of cement. Specific Gravity is found to be 2.56

\subsection{Fine Aggregates}

Manufactured sand is used as fine aggregate in this study conforming to the requirements of IS: 383-1970. Specific Gravity is found to be 2.65

\subsection{Quartz Sand}

The quartz sand was used from locally available source. Different sizes of Quartz sand such as $100 \mathrm{~mm}$ mesh, 200mm mesh and 300mm mesh sizes are used in this study. Specific gravity of Quartz sand is 2.66 


\subsection{Coarse Aggregates}

Coarse aggregate of $12.5 \mathrm{~mm}$ down size is used conforming to the requirements of IS: $383-1970$.The Specific Gravity is found to be 2.7

\subsection{Water}

Water used for the study was potable water conforming as per IS: 456-2000.

\subsection{Steel Fibers}

The Fibers are used to increase tensile capacity and improve ductility. Hooked bar steel strands are used in this study having diameter of $0.2 \mathrm{~mm}$, length of $30 \mathrm{~mm}$ and aspect ratio of 60 .

\subsection{Chemical Admixtures}

Korean based M70 Dyn plasticizer is used. It is a PC based new generation Hyper Plasticizer specially designed for Self-Compacting Concrete. Suitable for precast concrete industry and high performance concrete production. Water reduction up to $40 \%$ at low dosages.

\section{FRESH PROPERTIES TEST}

The main aim of these tests is to understand the behavior of fresh UHP-Self Compacting Concrete i.e. Flow ability of SCC, Filling ability and Passing ability of SCC. The fresh properties of UHPFC are estimates using the procedure used for SCC as per EFNARC - standard code of reference. The tests results of Mix 1 and Mix2 is as shown in Table 1 and Table 2.

\section{MIX DESIGN}

The Study includes the method or the approach used in arriving a proper dense concrete mix or the proportioning of various concrete materials. As we know that there is no proper mix design procedure for UHFRC in any code of references across the country. The proportioning of various materials in this work is taken by taking reference of H.J.H. Brouwers et.al journal. In this chapter particle packing density method is used for the mix design of concrete. The typical Mix proportion of Mix 1 of w/c ratio 0.30 is shown in Table 3

Table 1 Results of Rheology of Mixes - UHPC Mix 1

\begin{tabular}{|l|l|l|l|l|l|l|}
\hline Test & w/b Ratio & 0.3 & 0.28 & 0.26 & 0.24 & Result \\
\hline \multirow{3}{*}{ Slump Flow } & Horizontal Dia. $(\mathrm{mm})$ & 720 & 700 & 670 & 650 & $600-800 \mathrm{~mm}$ \\
\cline { 2 - 8 } & $\mathrm{T}_{50} \mathrm{~cm}(\mathrm{sec})$ & 3 & 3 & 4 & 4 & 2 Sec. \\
\hline \multirow{2}{*}{ V -Funnel } & $($ Tr) Flow $(\mathrm{sec})$ & 8 & 9 & 10 & 11 & $6-12$ Sec. \\
\cline { 2 - 7 } & Flow at $\mathrm{T}_{5} \mathrm{~min}(\mathrm{sec})$ & 10 & 12 & 12 & 13 & $\leq$ Tr+3 \\
\hline J - Ring & $\mathrm{T}_{50} \mathrm{~cm}(\mathrm{sec})$ & 4 & 4 & 6 & 8 & $<10$ Sec. \\
\hline L - Box & Blocking ratio $\left(\mathrm{H}_{2} / \mathrm{H}_{1}\right)$ & 0.9 & 0.9 & 0.85 & 0.85 & $0.8-1$ \\
\hline U - Box & Diff in height $($ left limb - right limb) in $(\mathrm{mm})$ & 5 & 1 & 0.5 & 1 & Max 30mm \\
\hline
\end{tabular}

Table 2 Results of Rheology of Mixes - UHPC Mix2

\begin{tabular}{|l|l|l|l|l|l|l|}
\hline \multirow{2}{*}{ Test } & w/b Ratio & 0.3 & 0.28 & 0.26 & 0.24 & Results \\
\hline \multirow{3}{*}{ Slump Flow } & Horizontal $(\mathrm{mm})$ & 680 & 660 & 650 & 630 & $600-800 \mathrm{~mm}$ \\
\cline { 2 - 7 } & $\mathrm{T}_{50} \mathrm{~cm}(\mathrm{sec})$ & 3 & 4 & 4 & 3 & $2-5 \mathrm{Sec}$. \\
\hline \multirow{2}{*}{ V -Funnel } & (Tr) Flow $(\mathrm{sec})$ & 11 & 12 & 10 & 10 & 6 - 12 Sec. \\
\cline { 2 - 7 } & Flow at $\mathrm{T}_{5} \min (\mathrm{sec})$ & 13 & 14 & 12 & 11 & $\leq \mathrm{Tr}+3$ \\
\hline J - Ring & $\mathrm{T}_{50} \mathrm{~cm}(\mathrm{sec})$ & 5 & 7 & 7 & 8 & $<10 \mathrm{Sec}$. \\
\hline L - Box & Blocking ratio $\left(\mathrm{H}_{2} / \mathrm{H}_{1}\right)$ & 0.9 & 0.85 & 0.9 & 0.85 & $0.8-1$ \\
\hline U - Box & Diff in height $($ left limb - right limb) in $(\mathrm{mm})$ & 0 & 1 & 1 & 0 & Max 30mm \\
\hline
\end{tabular}

Table 3 TYPICAL MIX FOR ONE BATCH OF W/C RATIO 0.30

\begin{tabular}{|l|l|l|l|l|l|}
\hline Total volume $=0.006 \mathrm{~m}^{3}$ & & Weight in $\mathrm{kg}$ & $\begin{array}{l}\text { Specific } \\
\text { Gravity }\end{array}$ & $\begin{array}{l}\text { Weight/ Sp. } \\
\text { Gg. }\end{array}$ & Units \\
\hline Cement & $=$ & 4.23 & 3.15 & 1.34285 & \\
\hline Micro Silica (10\%) & $=$ & 0.42 & 2.4 & 0.175 & \\
\hline Metakaolin (5\%) & $=$ & 0.21 & 2.56 & 0.08203 & \\
\hline M -Sand & $=$ & 7.2 & 2.65 & 2.73764 & \\
\hline Quartz Sand & $=$ & 1.35 & 2.66 & 0.50751 & \\
\hline SP $(0.65 \%)$ & $=$ & 0.031 & 1.1 & 0.0281 & \\
\hline Fibers $(0.5 \%)$ & $=$ & 0.024 & 7.6 & 0.0031 & \\
\hline Water & $=$ & 1.449 & - & 1.449 & \\
\hline
\end{tabular}




\begin{tabular}{|l|l|l|l|l|l|}
\hline Total & $=$ & 14.91 & & 6.33 & \\
\hline \hline Total Cementitious Material & $=$ & 4.86 & & & $\mathrm{~kg} / \mathrm{m}^{3}$ \\
\hline Total in $\mathrm{m}^{3}$ & $=$ & & 0.00633 & & $\mathrm{~m}^{3}$ \\
\hline W/C ratio & $=$ & $\begin{array}{l}\text { wt of water/ total } \\
\text { cement material }\end{array}$ & 0.298 & & \\
\hline \hline Cement & $=$ & cement/total in $\mathrm{m} 3$ & 668.73 & & $\mathrm{~kg} / \mathrm{m}^{3}$ \\
\hline \hline Micro Silica & $=$ & 66.87 & & & $\mathrm{~kg} / \mathrm{m}^{3}$ \\
\hline \hline Metakaolin & $=$ & 33.2 & & $\mathrm{~kg} / \mathrm{m}^{3}$ \\
\hline \hline M -Sand & $=$ & 1200 & & & $\mathrm{~kg} / \mathrm{m}^{3}$ \\
\hline FA $(55 \%)$ & $=$ & 660 & & & $\mathrm{~kg} / \mathrm{m}^{3}$ \\
\hline CA $(45 \%)$ & $=$ & 540 & & & $\mathrm{~kg} / \mathrm{m}^{3}$ \\
\hline Quartz Sand & $=$ & 225 & & $\mathrm{~kg} / \mathrm{m}^{3}$ \\
\hline Fibers & $=$ & 4.025 & & & $\mathrm{~kg} / \mathrm{m}^{3}$ \\
\hline Water & $=$ & 230.61 & & $\mathrm{~kg} / \mathrm{m}^{3}$ \\
\hline Total Concrete Density & $=$ & 2428.43 & & $\mathrm{~kg} / \mathrm{m}^{3}$ \\
\hline
\end{tabular}

\section{DURABILITY TEST ON HARDENED} CONCRETE

The durability of concrete is its resistance to the aggressive environmental conditions. High strength concrete is generally more durable than low strength concrete. In the situations when the high strength is not necessary but the conditions of exposure are such that high durability is vital, the durability requirement will determine the water-cement ratio to be used.

\subsection{Acid Test}

As per ASTM 642 This test is done to determine the loss of weight and loss of compressive strength after 28 days of curing in Hydrochloric acid. But weight of the concrete specimens sometimes increases due to the pores present in the specimen as in this case. $5 \%$ of $\mathrm{HCl}$ is mixed with $95 \mathrm{ml}$ of water in order to obtain $100 \mathrm{ml}$ of solution. The results of the test for Mix 1 and Mix 2 are shown in Table 4 and Table 5. Graphical representation is shown for this test in Fig1, Fig 2, Fig 3 and Fig 4.

Table 4 Compressive Strength of UHPC Mix 1 Specimens Immersed In HCl Solution

\begin{tabular}{|l|l|l|l|l|l|}
\hline SL NO & W/C ratio & $\begin{array}{l}\text { Avg Weight of } \\
\text { Specimen before } \\
\text { immersion in solution } \\
(\mathrm{Kg})\end{array}$ & $\begin{array}{l}\text { Avg 28 Days Weight of } \\
\text { Specimen after } \\
\text { immersion in HCl } \\
\text { solution }(\mathrm{Kg})\end{array}$ & $\begin{array}{l}\text { Normalised } \\
\text { Compressive Strength } \\
\text { before immersion } \\
\text { (MPa) }\end{array}$ & $\begin{array}{l}\text { Avg. Compressive } \\
\text { Strength after } \\
\text { immersion }(\mathrm{MPa})\end{array}$ \\
\hline 1 & 0.3 & 2.27 & 2.26 & 99.95 & 75.23 \\
\hline 2 & 0.28 & 2.2 & 2.19 & 105.73 & 79 \\
\hline 3 & 0.26 & 2.05 & 2.03 & 111.73 & 91.37 \\
\hline 4 & 0.24 & 2.01 & 2.0 & 115.83 & 97 \\
\hline
\end{tabular}

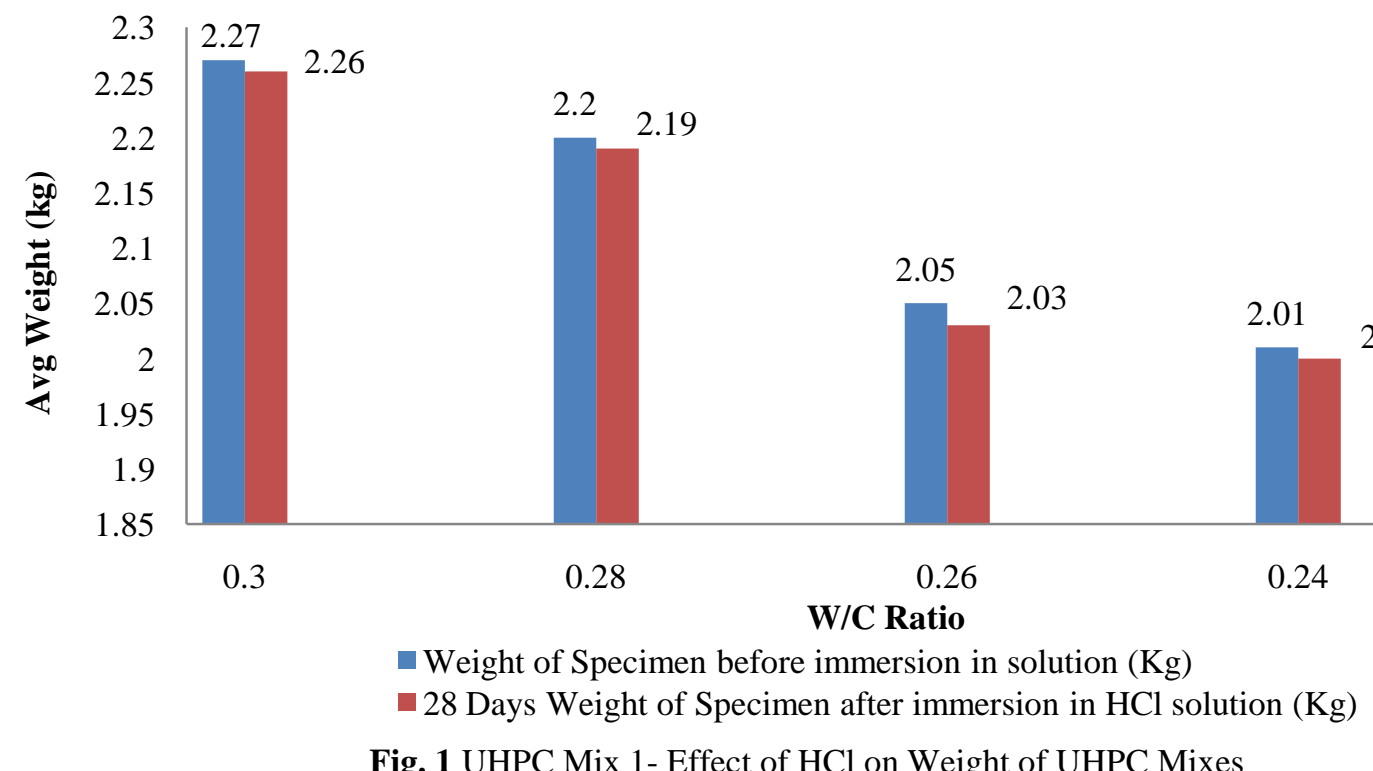

Fig. 1 UHPC Mix 1- Effect of $\mathrm{HCl}$ on Weight of UHPC Mixes 


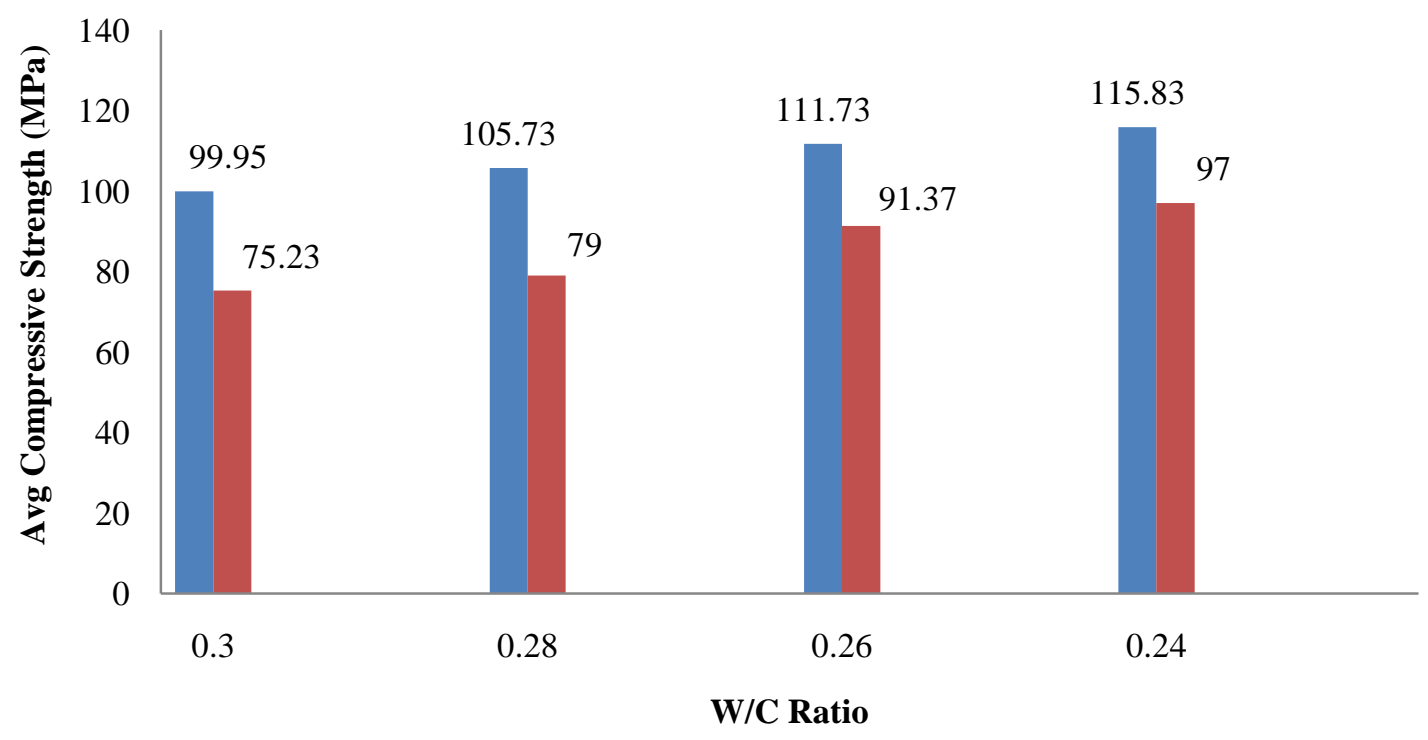

- Normalised Compressive Strength before immersion (Mpa)

avg. Compressive Strength after immersion (MPa)

Fig. 2 UHPC Mix 1- Effect of $\mathrm{HCl}$ on Strength of UHPC Mixes

Table 5 Compressive Strength of UHPC Mix 2 specimens immersed in $\mathrm{HCl}$ solution

\begin{tabular}{|l|l|l|l|l|l|}
\hline SL NO & W/C ratio & $\begin{array}{l}\text { Avg Weight of } \\
\text { Specimen before } \\
\text { immersion in solution } \\
(\mathrm{Kg})\end{array}$ & $\begin{array}{l}\text { Avg 28 Days Weight of } \\
\text { Specimen after } \\
\text { immersion in HCl } \\
\text { solution }(\mathrm{Kg})\end{array}$ & $\begin{array}{l}\text { Normalised } \\
\text { Compressive Strength } \\
\text { before immersion } \\
(\mathrm{MPa})\end{array}$ & $\begin{array}{l}\text { Avg. Compressive } \\
\text { Strength (MPa) }\end{array}$ \\
\hline 1 & 0.3 & 2.32 & 2.31 & 89.48 & 73.83 \\
\hline 2 & 0.28 & 2.29 & 2.27 & 95.31 & 78.23 \\
\hline 3 & 0.26 & 2.25 & 2.24 & 97.22 & 90.13 \\
\hline 4 & 0.24 & 2.22 & 2.21 & 98.48 & 96.97 \\
\hline
\end{tabular}

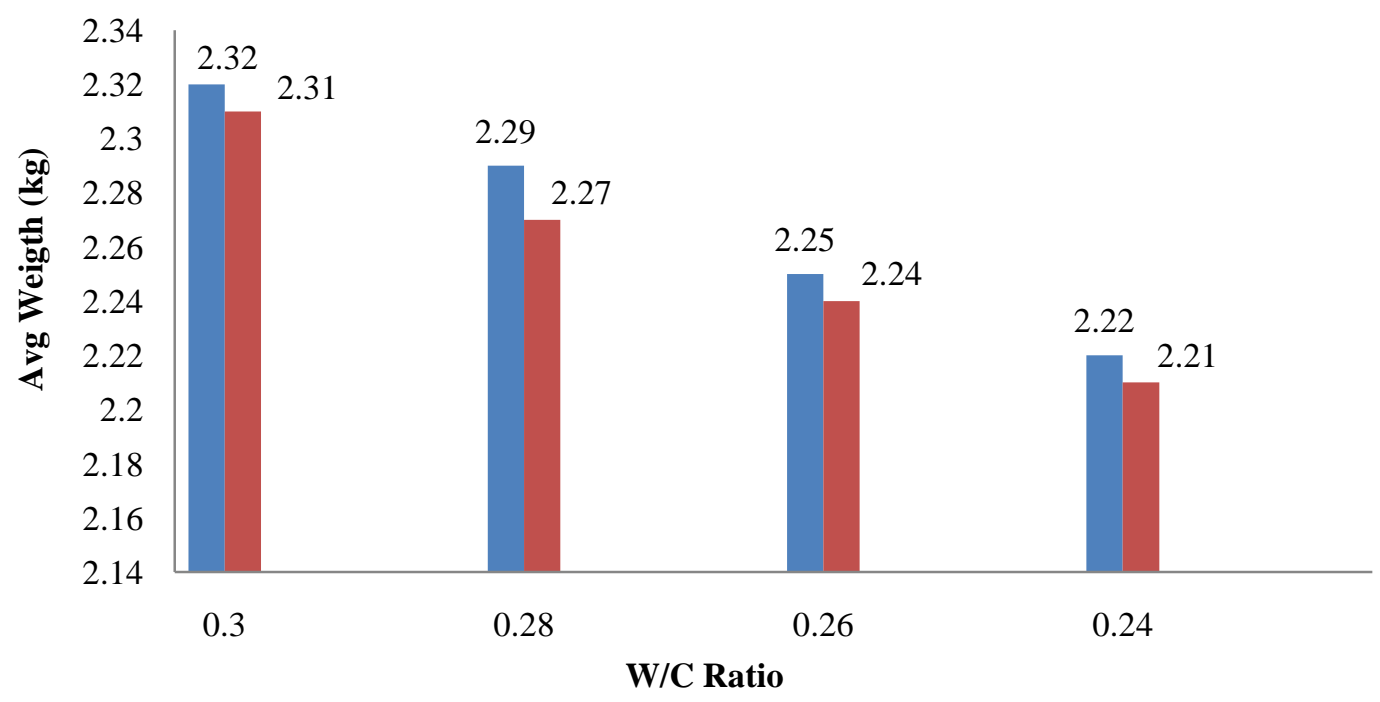

- Weight of Specimen before immersion in solution $(\mathrm{Kg})$

- 28 Days Weight of Specimen after immersion in $\mathrm{HCl}$ solution $(\mathrm{Kg})$

Fig.3 UHPC Mix 2- Effect of HCl Solution on Weight of Mixes 


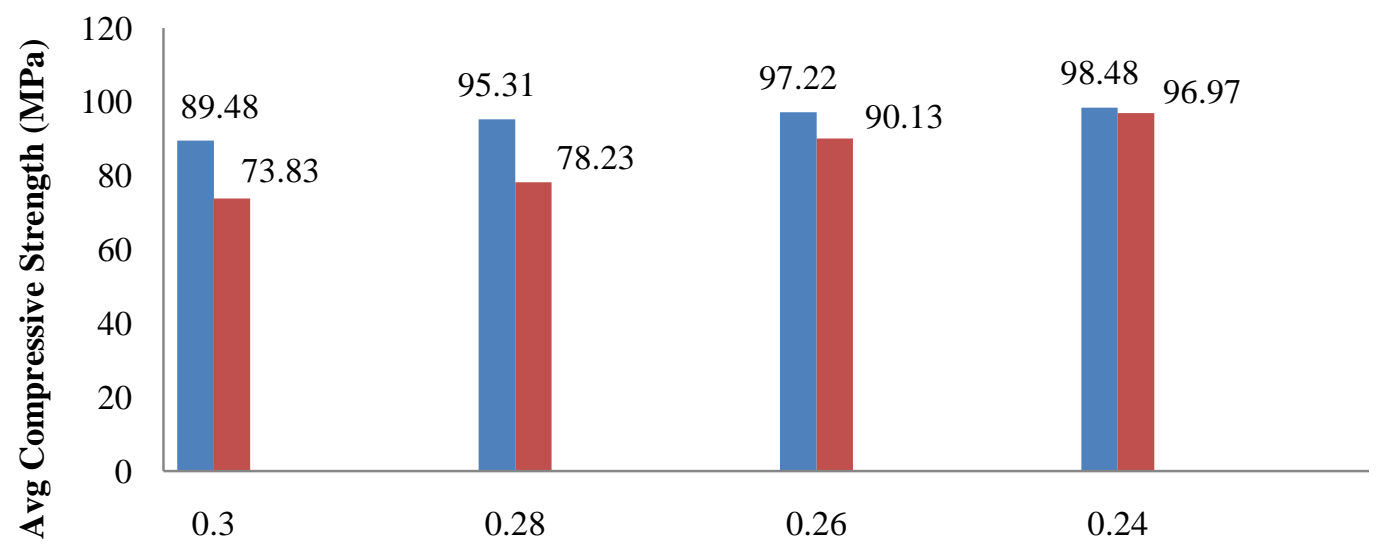

W/C Ratio

- Normalised Compressive Strength before immersion (Mpa)

- Avg. Compressive Strength (MPa)

Fig.4 UHPC Mix 2- Effect of HCl Solution on Strength of Mixes

\subsection{Chloride Ponding Test}

This test is done to determine the loss of weight and loss of compressive strength after 28 days of curing in Sodium Chloride solution. But weight of the concrete specimens sometimes increases due to the pores or the voids present inside the specimen.
$5 \%$ of $\mathrm{NaCl}$ is mixed with $95 \mathrm{ml}$ of water in order to obtain $100 \mathrm{ml}$ of solution. The results of the test for Mix 1 and Mix 2 are shown in Table 6 and Table 7. Graphical representation is shown for this test in Fig5, Fig 6, Fig 7 and Fig 8.

Table 6 Compressive Strength Of UHPC Mix 1 Specimens Immersed In Nacl Solution

\begin{tabular}{|l|l|l|l|l|l|}
\hline & W/C ratio & $\begin{array}{l}\text { Avg Weight of } \\
\text { Specimen before } \\
\text { immersion in } \\
\text { solution (Kg) }\end{array}$ & $\begin{array}{l}\text { Avg 28 Days } \\
\text { Weight of } \\
\text { Specimen after } \\
\text { immersion in NaCl } \\
\text { solution (Kg) }\end{array}$ & $\begin{array}{l}\text { Normalised } \\
\text { Compressive } \\
\text { Strength before } \\
\text { immersion (MPa) }\end{array}$ & $\begin{array}{l}\text { Avg. Compressive } \\
\text { Strength after } \\
\text { immersion (MPa) }\end{array}$ \\
\hline 1 & 0.3 & 2.28 & 2.26 & 99.95 & 76.6 \\
\hline 2 & 0.28 & 2.22 & 2.2 & 105.73 & 85.37 \\
\hline 4 & 0.26 & 2.18 & 2.16 & 111.73 & 93.1 \\
\hline
\end{tabular}

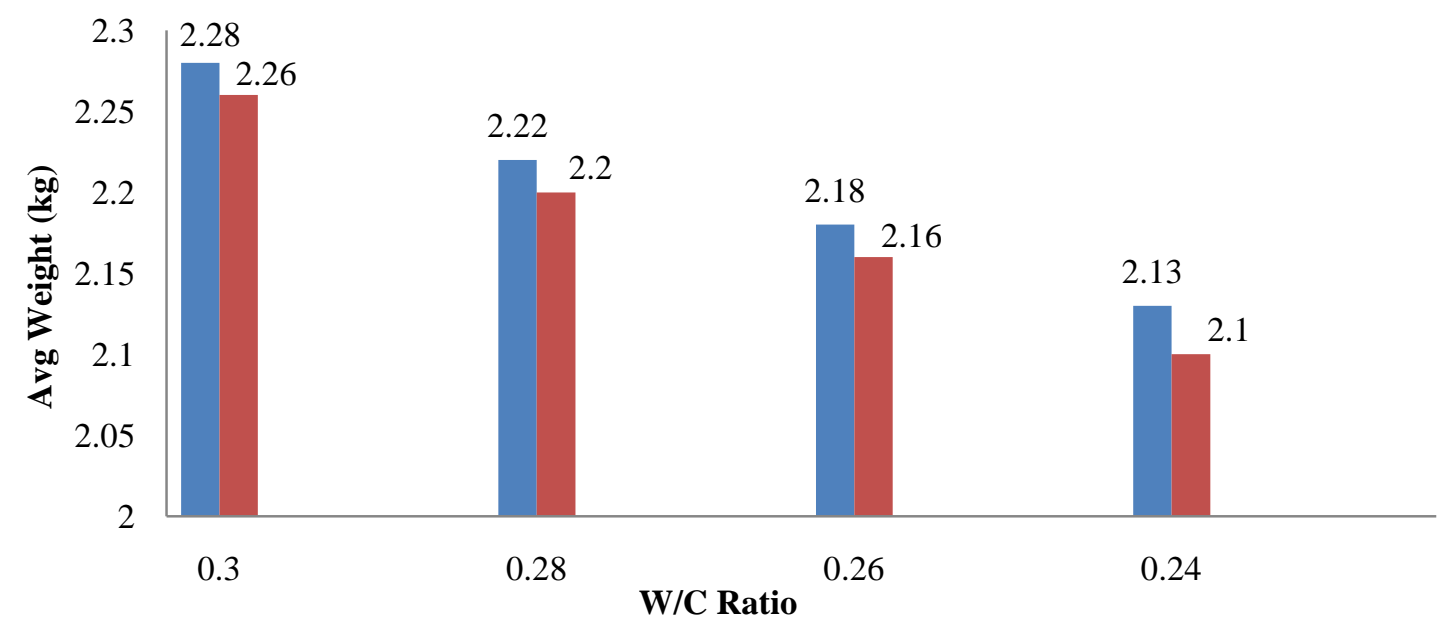

- Avg Weight of Specimen before immersion in solution $(\mathrm{Kg})$

- Avg 28 Days Weight of Specimen after immersion in $\mathrm{NaCl}$ solution $(\mathrm{Kg})$

Fig. 5 UHPC Mix 1 - NaCl Immersed Specimen on Weight 


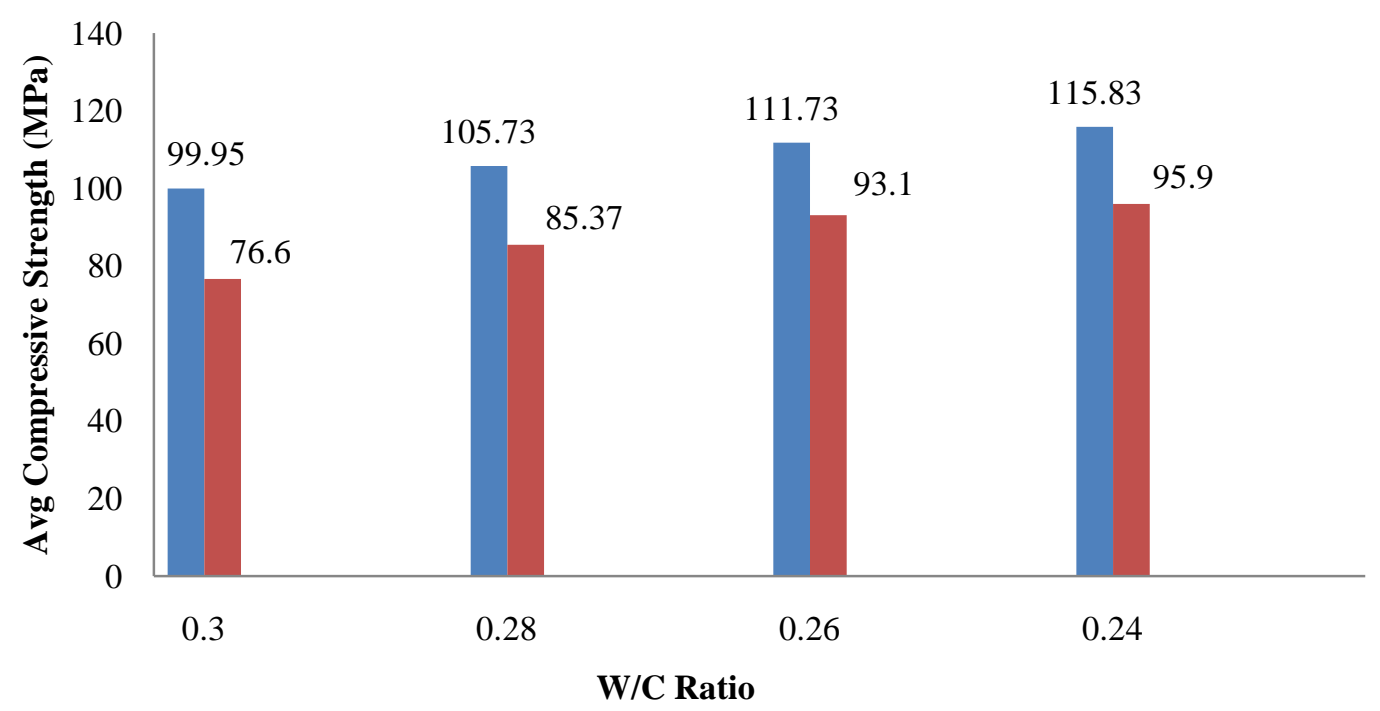

- Normalised Compressive Strength before immersion (Mpa)

Avg. Compressive Strength after immersion (MPa)

Fig.6 UHPC Mix1 - NaCl Immersed Specimen on Strength

Table 7 Compressive Strength Of UHPC Mix 2 Specimens Immersed In Nacl Solution

\begin{tabular}{|l|l|l|l|l|l|}
\hline SL NO & W/C ratio & $\begin{array}{l}\text { Avg Weight of } \\
\text { Specimen before } \\
\text { immersion in } \\
\text { solution }(\mathrm{Kg})\end{array}$ & $\begin{array}{l}\text { Avg 28 Days } \\
\text { Weight of } \\
\text { Specimen after } \\
\text { immersion in NaCl } \\
\text { solution }(\mathrm{Kg})\end{array}$ & $\begin{array}{l}\text { Normalised } \\
\text { Compressive } \\
\text { Strength before } \\
\text { immersion (MPa) }\end{array}$ & $\begin{array}{l}\text { Avg. Compressive } \\
\text { Strength after } \\
\text { immersion (MPa) }\end{array}$ \\
\hline 1 & 0.3 & 2.25 & 2.23 & 89.48 & 72.3 \\
\hline 2 & 0.28 & 2.2 & 2.19 & 95.31 & 81.97 \\
\hline 3 & 0.26 & 2.18 & 2.16 & 97.22 & 87.6 \\
\hline 4 & 0.24 & 2.15 & 2.14 & 98.48 & 91.37 \\
\hline
\end{tabular}

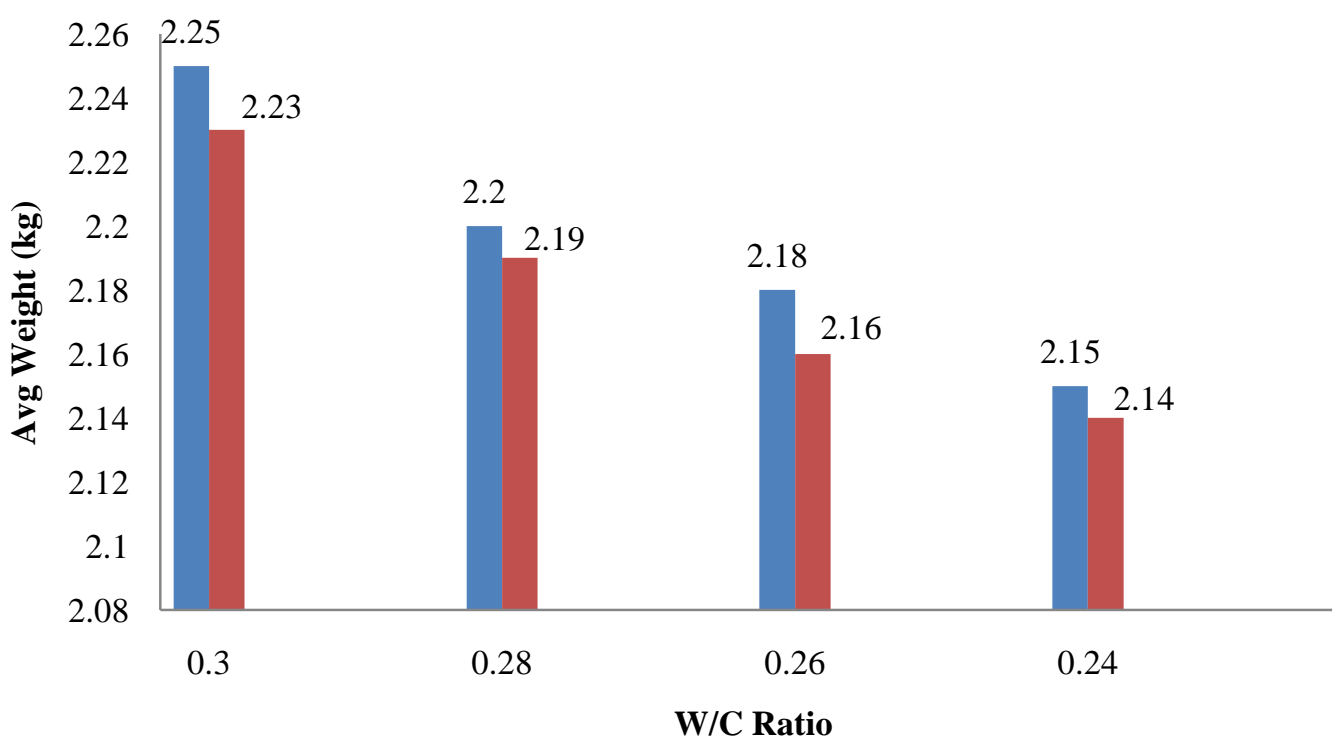

- Avg Weight of Specimen before immersion in solution $(\mathrm{Kg})$

- Avg 28 Days Weight of Specimen after immersion in $\mathrm{NaCl}$ solution $(\mathrm{Kg})$

Fig.7- UHPC Mix 2 - Effect of Immersion of Specimens in $\mathrm{NaCl}$ solution on Weight 


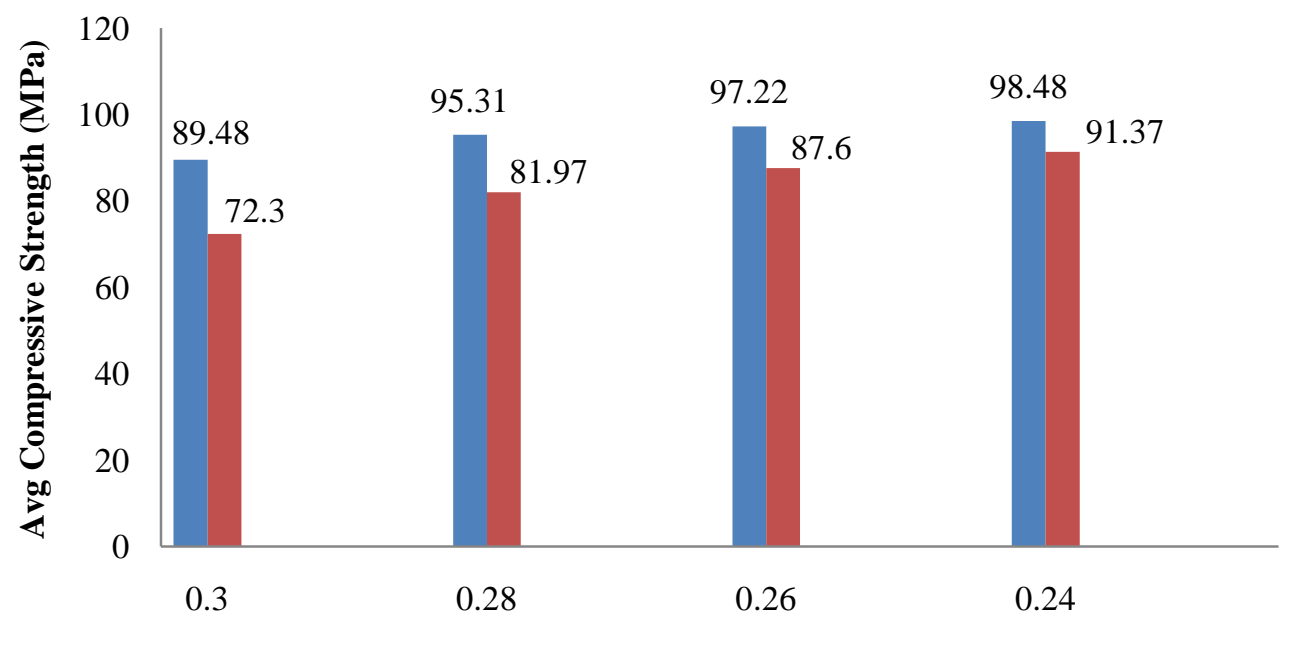

W/C Ratio

- Normalised Compressive Strength before immersion (Mpa)

- Avg. Compressive Strength after immersion (MPa)

Fig. 8 - UHPC Mix 2 - Effect of Immersion of Specimens in $\mathrm{NaCl}$ solution on Strength

\section{CONCLUSION}

This chapter includes summary of all the test results of durability property of concrete by using various cementitious materials and mineral admixtures, etc. The Discussion is as follows

1. The purpose of this study is to understand the durability behavior of UHPC subjected to various tests.

2. Micro Silica (10\%) and Metakaolin (5\%) was used as mineral admixture as partial replacement of cement and steel strands $(0.5 \%)$ is used as reinforcement.

3. Superplasticizer having $40 \%$ water reduction (M70 Dyn) is used for the study.

4. Since there is no proper procedure and guidelines for Mix design of UHPC, the design is carried out by Particle packing density method.

5. In Acid attack test Mix 1 gives more strength compared to Mix 2 since mix 1 specimens are compacted with more fine particles. Max Strength of Mix 1 was found to be $97 \mathrm{MPa}$ for $\mathrm{W} / \mathrm{C}$ ratio of 0.24 , for $\mathrm{W} / \mathrm{C} 0.24$ of Mix $96 \mathrm{MPa}$.

6. In Chloride attack test Mix 1 gives more strength compared to Mix 2 since mix 1 specimens are compacted with more fine particles. Max Strength of Mix 1 was found to be $95.9 \mathrm{MPa}$ for $\mathrm{W} / \mathrm{C}$ ratio of 0.24 , for W/C 0.24 of Mix 91.3 MPa.

7. From the discussions on the results of UHPC mixes, it may be concluded that the strength of UHPC mixes is more without coarse aggregates than with coarse aggregates at higher cementitious content than with lower cementitious content.

\section{REFERENCES}

[1] A. Elahi, P. A. M. Basheer, S. V. Nanukuttan and Q. U. Z. Khan, "Mechanical and Durability Properties of High Performance Concretes Containing Supplementary Cementitious Materials,"
Construction and Building Mate- rials, Vol. 24, No. 3, 2010, pp. 292-299.

[2] B. B. Patil and P. D. Kumbhar, "Strength and Durability Properties of High Performance Concrete Incorporating High Reactivity Metakaolin," International Journal of Modern Engineering Research, Vol. 2, No. 3, 2012, pp. 1099-1104.

[3] Bonneau, O., M. Lachemi, E. Dallaire, J. Dugat, and P.-C. Aïtcin, "Mechanical Properties and Durability of Two Industrial Reactive Powder Concretes," ACI Materials Journal, V. 94, No. 4, July-August 1997, pp. 286-290.

[4] Bonneau, O., C. Poulin, J. Dugat, P. Richard, and P.C. Aïtcin, "Reactive Powder Concretes: From Theory to Practice," Concrete International, April 1996, pp. 47-49.

[5] Cheyrezy, M., V. Maret, and L. Frouin, "Microstructural Analysis of RPC (Reactive Powder Concrete)," Cement and Concrete Research, V. 25, No. 7, 1995, pp. 1491-1500.

[6] Dugat, J., N. Roux, and G. Bernier, "Mechanical Properties of Reactive Powder Concretes," Materials and Structures, V. 29, No. 188, 1996, pp. 233-240.

[7] Richard, P., and M. Cheyrezy, "Composition of Reactive Powder Concretes," Cement and Concrete Research, V. 25, No. 7, 199, pp. 1501-1511.

[8] Roux, N., C. Andrade, and M. Sanjuan, "Experimental Study of Durability of Reactive Powder Concretes," Journal of Materials in Civil Engineering, V. 8, No. 1, Feb. 1996, pp. 1-6.

[9] Sundararaman S and S Azhagarsamy, "Performance of Ultra High Performance Concrete Containing Mineral Admixtures", SSRG International journal of Civil Engineering Vol: 2, Issue 10, (October 2015).

[10] V. G. Ghorpade and H. S. Rao, "Chloride Ion Permeability Studies of Metakaolin Based High Performance Concrete," International Journal of 
Engineering Science and Technology, Vol. 3, No. 2, 2011, pp. 1617-1623.

[11] V. Malagavelli and P. N. Rao, "High Performance Con- crete with Ggbs and Robo Sand," International Journal of Engineering Science and Technology, Vol. 2, No. 10, 2010, pp. 5107-5113.

[12] K. Yildiz and L. O. Ugur, "Examination of Durablity of High Performance Concrete (HPC) That Has Been Sub- jected to $\mathrm{MgSO} 4$ and $\mathrm{NaCl}$ Corrosion against Freezing and Thawing," Scientific Research and Essay, Vol. 4, No. 9, 2009, pp. 929-935.

[13] Satish.D, Ramesh Manoli, Shiva Kumar KS "An Experimental investigation on confined hybrid geopolymer concrete", International Journal of Research in Engineering and Technology, Vol 05, Issue 07, July 2016, pp 49-55.

\section{BIOGRAPHIES}

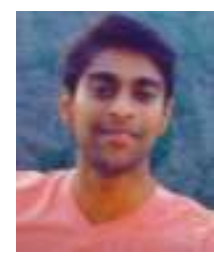

MONISH S, M.Tech -Civil Structural Engineering, P G Student, Global Academy of Technology

manish.monish@gmail.com

Cell No - 9035412090

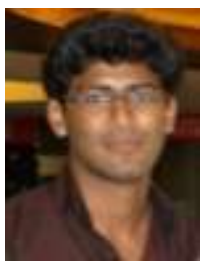

SHIVA KUMAR K S, M.Tech - Civil Structural Engineering, Assistant Professor, Department of Civil Engineering, Global Academy of Technology, Rajarajeshwari Nagar, Bangalore- 560098

shibks143@gmail.com

Cell No - 9880260473

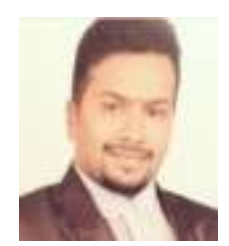

MANOJ V, M.Tech - Civil Structural Engineering, P G Student, Global Academy of Technology,

Manojvconcrete90@gmail.com

Cell No - 9611980095 